\title{
Managing people with language: language policy, planning and practice in multilingual blue-collar workplaces
}

\section{Kellie Gonçalves ${ }^{1}$}

Received: 8 July 2020 / Accepted: 8 July 2020 / Published online: 25 August 2020

(c) Springer Nature B.V. 2020

Against the backdrop of global mobilities - the unprecedented circulation of people and socio-cultural practices-this special issue of Language Policy centers on the latest conditions of language policy, planning and practices taking place in diverse 'blue-collar' workplaces around the world as a result of postmodern economies that have witnessed an expansion of precarious working conditions (Standing 2011; Serwe in press). Currently, we are residing in what Elliott and Urry have termed 'the golden age of mobility' where "massive social changes are implicated in the everincreasing movement of people, things, capital, information and ideas around the globe" (2010: ix). Within this context, language as a resource-whether symbolic, interactional, material or ideological-flows, changes and is used by specific and often very powerful social agents to manage individuals in their daily workplaces. Historically oriented scholars may advocate that what we are experiencing today in terms of globalizing forces and transnational migration is nothing new (Kellner 2002). The perspective taken in this issue is that while globalization and transnational interdependencies (Vertovec 2009) are not new, they have and continue to affect the rise of a new globalized economy and thus a 'new', international division of labor (Lutz 2011), which, among other corollaries, affects how socio-cultural practices, one of which is language, is being utilized, conceptualized, practiced and managed in innovative and different ways by both employers and employees in various workplace contexts globally.

Adopting a transformationalist perspective of globalization means acknowledging that we live in an already globalized world where national boundaries are becoming more permeable (Coupland 2013) based on particular interests of certain nationstates. This means that we are faced with not necessarily new challenges, but varying degrees, speeds, and shifts of existing social processes connected to different political, economic, and cultural systems. Two of these processes pertain to individuals'

Kellie Gonçalves

kellie.goncalves@uni-koeln.de

1 MultiLing, University of Oslo, Oslo, Norway 
increased mobility for economic reasons and the massive shift of tertiary work being dispersed on the global level, where workers' language skills and their ostensible commodification have been regarded as a central tool of the new global economy (Cameron 2000, 2005; Heller 2003, 2010; Duchêne 2009; Urciuoli and LaDousa 2013; Muth and Del Percio 2018; among others). Much of this work has been influenced by the dominant neoliberal narrative of commodification which marketizes everything (Holborow 2018: 58) and has coopted just about everyone (Pennycook in press). This line of argumentation has not gone unquestioned especially by scholars exploring the political economy of language through a Marxist or quasi-Marxist perspective (Holborow 2015, 2018; Block 2018).

Recent trends and future directions within the field of language policy that are concerned with both ontological and epistemological elements (Pérez-Milans and Tollefson 2018: 728) such as the saliency of employing critical approaches, ethnography and addressing ethical issues in contemporary LPP through researchers' reflexivity are addressed in this special issue. Indeed, different ways of thinking about and tackling research on language and work are approached through distinct epistemological lenses acquired through researchers' own disciplinary training, beliefs systems and ideological biases together with the sociohistorical structures and context that shape each study's setting. While the pairing of language and work as a phenomenon to be studied isn't really all that new (Boutet 2012; Hiss 2017), theories of economic and labor-market developments continue to transform. For example, the hegemonic discourses regarding the shift from Fordism to post-Fordism has been somewhat abandoned over the last decades and exchanged for a different narrative, which underscores creative industries, the 'new' knowledge economy, and 'new' capitalism along with it, within different schools of thought (i.e. transformationalist, autonomist). For McDowell and Dyson (2011), both of these schools neglect so-called 'reproductive' employment and affective labor, many of which fall into the category of blue-collar work (See Gonçalves and Schluter 2017; Gonçalves and Kelly-Holmes in press), which bears remnants of the 'old' economy in the era of industrial production.

The term 'blue-collar' is a 'fuzzy' and problematic category (Arnold and Bongiovi 2013), but is used here to understand working-class labor that is by definition temporary, low status and incorporates some type of physical labor based on paid hourly wages (Lederer 1979). According to Wickman (2012), referring to workers by the colors of their collars dates back to the 1800s in the US, but this type of labeling in order to discriminate by occupation, social status and class came into effect in the early $20^{\text {th }}$ century. In fact, talking about workers by the colors of their collars, whether white or blue, dates back to the early twentieth century in the US, where the term "blue collar" was propagated in 1930 and first used in the New York Times in 1945. Following the second World War, both "white collar" and "blue collar" were popularized and disseminated throughout the US and eventually beyond, followed by occupational terms including pink, green and gold collar work, and most recently, no-collar work. ${ }^{1}$ There is no arguing that the repute and use of the term 'blue-collar'

\footnotetext{
1 'Pink-collar' work has largely been attributed to administrative and secretarial work that is highly feminine-gendered. The term 'green-collar' worker resulted from the environmental movement and used to depict individuals working in areas of conservation and sustainability. The term 'gold-collar' worker emerged in the 1980s to refer to high status professions including engineering, medicine, law and
} 
has increased in recent years due to its association and frequent mention within the context of US politics especially as it pertains to Donald Trump's former and current political campaign agenda in forging coalitions and targeting the Mid-West and so-called "blue-collar regions" of the United States, well known for their manufacturing industries (Douthat 2018; Trip 2019).

Historically, blue-collar work has been and continues to be regarded as 'unskilled' (although cf. Vigouroux 2017 for a counter-argument on skills) and has traditionally not been the focus of scholars researching language and the workplace (Holmes 2012). While working-class speech has received considerable attention as a sociolinguistic category, looking at the actual language work that blue-collar workers do has and continues to be underrepresented within sociolinguistic studies. Early studies of language in the workplace focused on institutional discourse conducted in primarily monolingual and predominately white-collar workplaces (cf. Atkinson and Drew 1979; Gumperz and Cook-Gumperz 1982; Heritage 1985). More recent investigations into language practices within the workplace context have expanded to include multilingual worksites, but they too have favored white-collar workplaces (Coleman 1989; Clyne 1994; Drew and Sorjonen 1997; Evans and Green 2001; Hill and Zyl 2002; Koester 2006; Holmes 2007; Ehrenreich 2009; Pullin Stark 2009; Forey and Lockwood 2010; Kelly-Holmes and Mautner 2010; Holmes et al. 2012; Angouri 2014; Schnurr and Zayts 2017; Vine 2018; Thurlow 2020).

There are indeed several studies to date that focus on multilingual, blue-collar worksites: Goldstein's (1997) study of Portuguese women factory workers in Canada; Sunaoshi's (2005) study of workplace interactions and negotiations between American and Japanese workers in car-manufacturing companies; Barrett's (2006) work on the added advantages of Spanish language proficiency among employees in a Mexican restaurant in the U.S.; Nekvapil and Nekula's (2008) study of language management in a subsidiary of the Siemens VDO Automotive Corporation; Duchêne's (2009) study of multilingualism practices among migrant airport staff workers in Switzerland; Schluter's (2014) work on the hidden nature of Kurdish language use among Kurdish migrant workers in Istanbul eating establishments; Piller and Lising's (2014) study of language learning and use among temporary meat workers in Australia; Gonçalves's (2015) study of English use among domestic workers in the U.S.; Strömmer's (2016) study of cleaning personnel in Finland; Schneider's (2018) study of language choice and language ideologies among workers in the lobster and fishing industries in Belize; as well as the contributions in Gonçalves and Kelly-Holmes (in press). But not all of the studies listed above address language policy explicitly. Yet, issues surrounding language policy "arise every day and everywhere" (Hornberger 2015: 9) including workplace settings, a relatively new area of inquiry in mainstream language policy studies (Duchêne and Heller 2012; Gonçalves and Kelly-Holmes in press). The investigation of blue-collar workplaces, in

Footnote 1 (continued)

finance. The most recent term known as a 'no-collar' worker refers to professionals involved in the techindustry "who eschew collars altogether" (Wickman 2012). 
contrast to white-collar workplaces, emphasizes the informal process through which covert language policies within different multilingual settings take shape and are discursively legitimized by particular actors, organizations and institutions (Duchêne et al. 2013; Gonçalves and Schluter 2017).

In his calls for broadening the domains in which sociolinguists work, Spolsky $(2009,2018)$ has consistently advocated for a wider recognition of where language policy takes place naming workplaces as a salient albeit under-represented domain. In addition, he has urged scholars to investigate both implicit and so-called 'hidden policies' (Shohamy 2006) in addition to explicit ones. Investigating language policy within workplace settings has been influenced by language management theory (Jernudd and Neustupný 1987), where the focal point has been on "the identification of language problems by everyday speakers in the course of communication" (Nekvapil 2007) rather than starting at the "assumed manager's attempt to modify language practices (or beliefs) of others (Spolsky 2009: 11). Continued interest in the ways in which decisions are made to highlight different forms of social regulation, economic productivity and the role of language within these processes and interactional spaces of production and distribution have contributed and continue to contribute to a growing body of work where language practices, beliefs and management have been scrutinized at different levels and scales by different social actors, but more work is required.

Inquiries about existing language hierarchies needed for political, educational and social purposes where language policies and language practices (shaped by specific language ideologies usually at the state level) are almost always incompatible with one another and raise a number of intriguing questions about the somewhat ephemeral understanding of language practices within different sociolinguistic approaches (see Pennycook 2017 for an overview). In line with a "critical-constructivist sociolinguistics", the papers in this special issue explore and understand language as a "social practice with speakers drawing on all kinds of linguistic resources for their own purposes" (Bell 2013: 9), which include specific communicative practices, repertoires, "bits of language" (Blommaert 2010) as well as and often in conjunction with other semiotic means and artifacts (Gonçalves this volume, Theodoropoulou, this volume). In these ways, they are aligned with the recent paradigm shift in sociolinguistics, where the deployment of semiotic resources, one of which is language, allows for a fuller understanding of language practices in different contexts that are characterized by multiple mobilities and space-time compression at a specific historical moment.

A close look at the language practices of workers themselves also resonates with Holborow's (2018: 65) recent call to approach 'language work' "through the lived experience of the workers, rather than through the prism of management-speak or as a passive object of research". This raises the important point that blue-collar workplaces are rarely ever just blue-collar, but are found at the intersection of labor market changes that encompass a range of different types of workers (white, pink, blue, etc.) and thus various individual and collective competencies and their inherent values. These competencies may be cultural, symbolic, and/or material and required for the creation, production, and distribution of resources and the ways in which these get organized, regulated and deployed. But forms of labor, whether mental or 
manual "is a multi-skilled whole, involving a range of human capacities which are all put in motion at the same time" (Holborow 2018: 61). As such, it makes little sense to separate the mental from the manual or the linguistic from the non-linguistic activities since they are intricately intertwined despite some scholars' conviction that language work in late capitalism has replaced the often strenuous, physical labor of the past. It hasn't, at least not for all occupations. In fact, the productivity of physical labor continues to be pervasive in contemporary society compelling us to acknowledge that blue-collar employees are also legitimate language workers despite their underrepresentation in language and workplace studies (Holmes 2012; Gonçalves and Schluter 2017; Lønsmann and Kraft 2018; Gonçalves and Kelly-Holmes in press).

The dearth of scholarly work focusing on language and blue-collar workers may be due to the methodological challenges (Holmes 2012) it represents for researchers, researchers' own bourgeois networks and agendas (Thurlow 2020), or the fact that many of these workers perform their jobs backstage (Goffman 1959) and therefore are not always readily visible and thus easily forgotten, left behind and excluded from academic scrutiny. The English proverb out of sight, out of mind comes to mind here referring to the ways in which people can easily lose touch with their surroundings, responsibilities and obligations if and when they do not necessarily demand our immediate attention. But this has epistemological repercussions when so much of the focus of language policy studies has been and continues to be located within educational contexts and settings.

According to Holmes, the lack of research in blue-collar worksites can be attributed to noise, dirt and discomfort. While these characteristics may not describe many blue-collar workplaces today, gaining access, trust concerns and the common currency of a shared language between participants and researchers are methodological hurdles that should not be underestimated. Indeed, many scholars might consider these challenges as common sense, but there seems to be some ideological work that requires some rendering in all of this. Let's begin with noise. Despite the noisy environments many of these workplaces present, research has still been successfully carried out, much of it from a (critical) ethnographic perspective such as in factories (Goldstein 1997; Piller and Lising 2014), car manufacturing companies (Sunaoshi 2005) airports (Duchêne 2009); construction sites (Kraft 2020; Theodoropoulou, this volume) and restaurants (Barrett 2006; Schluter 2014; Pennycook and Otsuji 2015; Gonçalves, this volume) to name but a few. While dirt inevitably arises in one form or another from these (and other) spaces of material creation, production and consumption, I must admit that I continue to struggle with the notion of discomfort because I wonder who exactly is discomfited? The participants, the researchers or both? As scholars of language policy and social scientists in general, a major concern is to give back to the communities and groups of people we study. Within the field of sociolinguistics, this has been termed by Cameron et al. (1992) as 'empowerment research' and by Wolfram (1993) as 'linguistic gratuity'. But how are we expected to give back when we are often consumed by our very own elitist work pursuits and performance measures within our neoliberal institutions (Gonçalves 2019)? As academics tucked away in our ivory towers we are often critiqued and criticized for fulfilling our own intellectual interests that are sharply severed from 
both the realities and practical concerns of daily life (Stockdill and Danico 2012, although see Ladegaard and Phipps' (2020) recent call for social activism within intercultural research). The sociolinguistic realities of blue-collar workers and the practical concerns of their daily lives, including precarious working conditions and tenuous migration status compounded by their attempts to learn language (Holmes et al., this volume), speak language, or even hide language use (Schluter, this volume) are themes explored in this volume.

For Schneider (2016), one reason why scholarship on lower-class individuals has been neglected has to do with academic orientations to formal education strategies and the 'ultimate goal of guiding students to attain norm-oriented linguistic skills' (2016: 4). The ramifications of not taking account of individuals' experiences who do not have formal higher-education (or whose education is not recognized), lack access and thus cannot afford language courses (both time and money-wise) are academically skewed and epistemologically biased. By not accounting for the ways in which these individuals acquire, learn or do not learn another language (especially the host language in question, Sherman and Homoláč, this volume) outside of traditional formal classroom settings, we are not only doing a disservice to less privileged and 'non-elite' society members, but to the fields of sociolinguistics and language policy more generally.

Blue-collar workplaces often consist of individuals who are located at the lowerend of the socio-economic scale and are largely comprised of migrant workers, who, in addition to traditional causes of migration such as economic collapse natural disaster, war and transformations of socio-political systems (cf. Lutz 2011), migrate due to a lack of viable employment options in their own home countries (which are often less developed nation-states) making foreign salaries the one and only credible source of income (Gonçalves and Schluter 2020). Questions of mobility and non-mobility of individuals are often assisted or blocked through bi-lateral agreements of both sending and receiving nation-states (Theodoropoulou, this volume) where countries rely on institutionalized, national policies and programs, which increase the scope of a state's political, economic and social bureaucracy to include or exclude migrants in highly regulated manners (Goldring 2002: 64).

According to the World Economic Forum (2020), there are approximately 272 million international migrants. These numbers make up roughly $3.5 \%$ of the world's population, and prior to the COVID 19 pandemic, these numbers were expected to grow, although the rate of this is difficult to predict given that international migration parallels economic crises, geopolitical tensions and conflicts, and stark instability. A glance at any online or offline media outlet confirms the volatility and grievance that dictate and navigate the ways in which many nation-states are dealing with issues where socio-cultural and political disarray remain at the forefront and largely determined by political-economic interests of primarily rich countries, corporations and individuals. We must therefore also ask ourselves about individuals who serve and are simultaneously burdened by such elite pursuits who are located at the opposite end of the socio-economic scale and how these decisions and policies from local to global affect their feeble migration statuses, mobility, work opportunities and overall life chances. Given current socio-political factors that have given rise to an "emergent class of itinerant, impoverished and insecure laborers" (Pennycook, in 
press), it is perhaps no surprise that such migration status is increasingly common and where employment status and citizenship rights of such individuals are most affected in times of economic crisis and instability (Hirsch and Naquin 2001). ${ }^{2}$ A 'disorderly Brexit' in the UK is a case in point, which could experience an estimated 22 billion pound loss in economic output due to expected staff shortages in manual and elementary services, where changes in immigration policies have been proposed (Malik 2019). This year, for example, Britain has announced the closing of its borders to unskilled workers and those who cannot speak English in an effort to revamp immigration laws, ending an era of cheap labor within the European Union in factories, warehouses, hotels and restaurants with plans to implement an Australian-style points system for individuals wanting to remain in Britain (O'Caroll et al. 2020). This is a clear case of language policy in the making. While such measures are drastic and have been met with criticism from employers and industry leaders alike, the resulting immigration bill is expected to pass through parliament.

This is just one recent and extreme example that highlights the interlocking complexity of socio-political and economic changes and instability that extend beyond supranational levels and where the restructuring of segmented labor markets, and where the current flow of migrants - who are also often multilingual speakers-will be significantly affected. Insisting on a certain level of English for unskilled workers shows how language is weaponized in such processes and policies. In fact, the stakes are high for both employers and employees making Pennycook's (in press) recent appeal for investigating the mechanisms through which language and labor operate collectively apt at this precise historical moment. The articles presented in this special issue highlight the ways in which managing workers (linguistically, semiotically and corporeally) gets done through both overt and covert language policies providing insight into the asymmetrical power relations within different communities of practice in a range of global workplace contexts such as restaurants, hotel kitchens, and construction sites to name but a few. The geographical coverage of these papers ranges from the North Atlantic archipelago of the Faroe Islands (Holmes et al.), to a small alpine village in Austria (Gonçalves) and extends to major urban hubs and capitals including Prague (Sherman and Homoláč), Istanbul (Schluter) and Doha (Theodoropoulou) and account for the ways in which language policies and people are managed in fluctuating centers and peripheries. In these ways, the papers presented here also simultaneously respond to the pressing crisis of both capitalism and democracy we are currently experiencing (Pérez-Milans and Tollefson 2018).

The contributions in this special issue are concerned with examining questions of language choice, language ideologies (Ricento 2000) and language policies, their connections to (and linguistic consequences of) particular economic arrangements and the ensuing opportunities (or lack thereof) that influence individuals' everyday lives (Shohamy 2006). Drawing on different theoretical frameworks and methodological approaches, the papers in this volume not only address issues of language

\footnotetext{
${ }^{2}$ Unpredictability and economic instability is what we are all currently experiencing with the COVID19 global pandemic but blue-collar workers in particular are suffering the most as many of them have lost their jobs overnight, may not have health insurance or guaranteed paid sick leave.
} 
practices within diverse workplace settings but also how both overt and covert language policies affect and are shaped by individuals' positions of class, race, ethnicity and gender within the political economy and address the following questions:

How do different political structures and transnational relations between institutions including labor markets affect the movement of blue-collar (and often migrant) workers globally? How is communication achieved between employers and employees from different socio-economic and socio-cultural backgrounds within diverse transnational fields? How is communication and how are specific language policies and practices in these workplaces being shaped by broader socio-political and economic forces of states at the national, regional and local levels? How do such processes account for the present-day challenges and social inequality faced by bluecollar workers' language resources and ensuing practices?

The investigation of discourse produced by employers and employees as well as the discourses surrounding language policy (Hult 2010) and planning at specific worksites allows us to reveal the complex structural dynamics at play on a microlevel, which are often (but not always) reflected in and constrained by macro level operations, which is a primary goal of this thematic issue. A secondary goal of this issue, therefore, entails interpretation of the micro-level findings with respect to the macro-level setting. A third goal of this issue aims to address methodological challenges of LPP (Ricento 2000; Hult and Johnson 2015) and their connections to the theoretical understanding of language policy in domains and sites that are currently underrepresented (García and Kelly-Holmes 2016: 2) within the field.

This work adds to existing literature on language policy by thinking 'outside the box' (García and Kelly-Holmes 2016: 2) by drawing attention to the ways in which language is being managed at different levels (ranging from the local to the global) and how such policies and ensuing practices perpetuate social inequality within workplace settings across various transnational, majority-language and minorityspeaking contexts (Wright 2004). Indeed, the contributions in this special issue acknowledge that language management, language choices and linguistic issues are never autonomous but the response to "social, political, economic, religious, ideological, emotional context in which human life goes" (Spolsky 2009: 9) where language differences "account for only a tiny part of prejudice, injustice and suffering (ibid.).

Acknowledgements This research was funded by the Research Council of Norway through its Centres of Excellence funding scheme 223265. I would like to thank Helen Kelly-Holmes, Robert Blackwood, Kate Menken and Miguel Pérez-Milans for their comments on earlier drafts of this introduction. All shortcomings are my own. I would also like to thank the following individuals, who served as external reviewers for this thematic issue: Loy Lising, Florian Hiss, Ben Rampton, Tommaso Milani, Marta Kirilova, Alastair Pennycook, Dominique Hess, Ruriko Otomo, Robert Blackwood, Maiju Strömmer, David Cassels Johnson, Kamilla Kraft, Nicola Bermingham, Kori Allan, Mireille McLaughlin, Stefan Serwe, Diana Camps and two anonymous reviewers. 


\section{References}

Angouri, J. (2014). The multilingual reality of the multinational workplace: Language policy and language use. Journal of Multilingual and Multicultural Development, 34(6), 564-581.

Arnold, D., \& Bongiovi, J. R. (2013). Precarious, informalizing, and flexible work. American Behavioral Scientist, 57, 289-308.

Atkinson, J. M., \& Drew, P. (1979). Order in court: The organisation of verbal interaction in judicial settings. London: Macmillan.

Barrett, R. (2006). Language ideology and racial inequality: Competing functions of Spanish in an Anglo-owned Mexican restaurant. Language in Society, 35(2), 163-204.

Bell, A. (2013). The guidebook to sociolinguistics. New York: Wiley.

Block, D. (2018). Political economy and sociolinguistics: Neoliberalism, inequality and social class. London: Bloomsbury.

Blommaert, J. (2010). The sociolinguistics of globalization. Cambridge: Cambridge University Press.

Boutet, J. (2012). Language workers: Emblematic figures of late capitalism. In A. Duchêne \& M. Heller (Eds.), Language in late capitalism (pp. 217-239). New York: Routledge.

Cameron, D. (2000). Styling the worker: Gender and the commodification of language in the globalized service economy. Journal of Sociolinguistics, 4, 323-347.

Cameron, D. (2005). Communication and commodification: Global economic change in sociolinguistic perspective. In G. Erreygers \& G. Jacobs (Eds.), Language, communication and the economy 16 (pp. 9-23). Amsterdam: John Benjamins Publishing.

Cameron, D., Frazer, E., Harvey, P., Rampton, M. B. H., \& Richardson, K. (1992). Researching language: Issues of power and method. London: Routledge.

Clyne, M. (1994). Inter-cultural communication at work: Cultural values in discourse. Cambridge: Cambridge University Press.

Coleman, H. (1989). The present and the future of work. In H. Coleman (Ed.), Working with language: A multidisciplinary consideration of language use in work contexts (pp. 109-128). Berlin: Mouton de Gruyter.

Coupland, N. (Ed.). (2013). The handbook of globalization. Malden: Blackwell Publishing.

Douthat, R. (2018). The White Strategy: Trump's winning coalition and its weaknesses. The New York Times. https://www.nytimes.com/2018/08/11/opinion/sunday/the-white-strategy.html?searchResu $1 \mathrm{tPosition}=8$.

Drew, P., \& Sorjonen, M. L. (1997). Institutional dialogue. London: Sage Publications Inc.

Duchêne, A. (2009). Marketing, management and performance: Multilingualism as a commodity in a tourism call center. Language Policy, 8(1), 27-50.

Duchêne, A., \& Heller, M. (2012). Language policy in the workplace. In B. Spolsky (Ed.), The Cambridge handbook of language policy (pp. 323-334). Cambridge: Cambridge University Press.

Duchêne, A., Moyer, M., \& Roberts, C. (Eds.). (2013). Language, migration and social (in)equalities. New York: Multilingual Matters.

Ehrenreich, S. (2009). English as a Lingua Franca in multinational corporations-Exploring business communities of practice. In A. Mauranen \& E. Ranta (Eds.), English as a Lingua Franca: Studies and findings (pp. 126-151). Newcastle: Cambridge Scholars Press.

Elliott, A., \& Urry, J. (2010). Mobile lives. London: Routledge.

Evans, S., \& Green, C. (2001). Language in post-colonial Hong Kong: The roles of English and Chinese in the public and private sectors. English World-Wide, 22(2), 247-268.

Forey, G., \& Lockwood, J. (Eds.). (2010). Globalization, communication and the workplace: Talking across the world. Lonodn: A\&C Black.

García, O. \& Kelly-Holmes, H. (2016). Editorial. Language Policy X, 1-2.

Goffman, E. (1959). The presentation of self in everday life. Garden City, NY: Doubleday Anchor Books.

Goldring, L. (2002). The Mexican State and Transmigrant Organizations: Negotiating the boundaries of membership and participation. Latin American Research Review, 37(3), 55-99.

Goldstein, T. (1997). Two languages at work: Bilingual life on the production floor. New York: Mouton de Gruyter.

Gonçalves, K. (2015). The pedagogical implications of ELF in a domestic migrant workplace. In H. Bowles \& A. Cogo (Eds.), International perspectives on English as a Lingua Franca (pp. 136-158). Houndmills: Palgrave MacMillan. 
Gonçalves, K. (2019). "What are you doing here, I thought you had a kid now?" The stigmatization of working mothers in academia-A critical self-reflective essay on gender, motherhood and the neoliberal academy. Gender and Language, 13(4), 469-487.

Gonçalves, K \& Kelly-Holmes, H. (eds.) (in press). Language, global mobilities and blue-collar workplaces. New York, Routledge.

Gonçalves, K., \& Schluter, A. (2017). "Please do not leave any notes for the cleaning lady, as many do not speak English fluently": Policy, power, and language brokering in a multilingual workplace. Language Policy, 16(3), 241-265.

Gonçalves, K., \& Schluter, A. (2020). Introduction: Language, inequality and global care work. International Journal of the Sociology of Language, 262, 1-15.

Gumperz, J. J., \& Cook-Gumperz, J. (1982). Interethnic communication in committee negotiations. In J. J. Gumperz (Ed.), Language and social identity (pp. 145-162). Cambridge: Cambridge University Press.

Heller, M. (2003). Globalization, the new economy and the commodification of language and identity. Journal of Sociolinguistics, 7(4), 473-492.

Heller, M. (2010). Paths to post-nationalism: A critical ethnography of language and identity. Oxford: Oxford University Press.

Heritage, J. (1985). Recent developments in conversation analysis. Sociolinguistics, 15, 1-18.

Hill, P., \& Zyl, S. V. (2002). English and multilingualism in the South African engineering workplace. World Englishes, 21(1), 23-35.

Hirsch, P. M., \& Naquin, C. E. (2001). The changing sociology of work and the reshaping of careers. London: Sage Publications.

Hiss, F. (2017). Workplace multilingualism in shifting contexts: A historical case. Language in Society, 46(5), 697-718

Holborow, M. (2015). Language and neoliberalism. New York: Routledge.

Holborow, M. (2018). Language, commodification and labour: The relevance of Marx. Language Sciences, 70, 58-67.

Holmes, J. (2007). Humour and the construction of Maori leadership at work. Leadership, 3(1), 5-27.

Holmes, J. (2012). Discourse in the Workplace. In K. Hyland \& B. Paltridge (Eds.), Continuum companion to discourse analysis (pp. 185-198). London: Continuum.

Holmes, J., Marra, M., \& Vine, B. (2012). Leadership, discourse and ethnicity. Oxford: Oxford University Press.

Hornberger, N. H. (2015). Selecting appropriate research methods in LPP research: Methodological rich points. In F. M. Hult \& J. C. Johnson (Eds.), Research methods in language policy and planning: A practical Guide (pp. 9-20). Chichester: Wiley-Blackwell.

Hult, F. M. (2010). Analysis of language policy discourses across the scales of space and time. International Journal of the Sociology of Language, 202, 7-24.

Hult, F. M., \& Johnson, J. C. (2015). Research methods in language policy and planning: A practical guide. Chichester: Wiley-Blackwell.

Jernudd, B. H., \& Neustupný, J. V. (1987). Language planning: for whom. In Proceedings of the international colloquium on language planning (pp. 69-84). Québec: Les Presses de L'Université Laval.

Kellner, D. (2002). Theorizing globalization. Sociological Theory, 20(3), 285-305.

Kelly-Holmes, H., \& Mautner, G. (Eds.). (2010). Language and the market. Houndmills: Palgrave Macmillan.

Koester, A. (2006). Investigating workplace discourse. London: Routledge.

Kraft, K. (2020). Trajectory of a language broker: Between privilege and precarity. International Journal of Multilingualism, 17(1), 80-96.

Ladegaard, H. J., \& Phipps, A. (2020). Intercultural research and social activism. Language and Intercultural Communication, 20(2), 67-80.

Lederer, M. (1979). Blue-collar jobs for women. Boston: Dutton.

Lønsmann, D. \& Kraft, K. (2018). Language in blue-collar workplaces. In B. Vine (Ed.). The Routledge handbook of language in the workplace. New York: Routledge.

Lutz, H. (2011). The new maids: Transnational women and the care economy. New York: Zed Books.

Malik, M. (2019). Disorderly Brexit-One-on-five blue-collar workers could be lost. The HR Director, 16 March. Retrieved from https://www.thehrdirector.com/business-news/brexit/one-five-blue-colla r-workers-lost358/

McDowell, L., \& Dyson, J. (2011). The other side of the knowledge economy: 'Reproductive' employment and affective labours in Oxford. Environment and Planning A, 43(9), 2186-2201. 
Muth, S., \& Del Percio, A. (2018). Policing for commodification: Turning communicative resources into commodities. Language Policy, 17(2), 129-135.

Nekvapil, J. (2007). From language planning to language management. Sociolinguistica, 20(1), 92-104.

Nekvapil, J., \& Nekula, M. (2008). On language management in multilingual companies in the Czech Republic. In A. J. Liddicoat \& R. B. Baldauf Jr. (Eds.), Language planning in local contexts (pp. 268-287). New York and Ontario: Multilingual Matters.

O'Caroll, L., Walker, P., \& Brooks, L. (2020). UK to close door to non-English speakers and unskilled workers. The Guardian. https://www.theguardian.com/uk-news/2020/feb/18/uk-to-close-door-tonon-english-speakers-and-unskilled-workers.

Pennycook, A. (2017). Language policy and local practices. In O. García, N. Flores, \& M. Spotti (Eds.), The Oxford handbook of language and society (pp. 126-140). Oxford: Oxford University Press.

Pennycook, A. (in press). Blue-collar work and multilingualism: 'C'est tough' In Gonçalves, K \& H. Kelly-Holmes (eds.) Language, global mobilities and blue-collar workplaces. New York, Routledge.

Pennycook, A., \& Otsuji, E. (2015). Making scents of the landscape. Linguistic Landscape, 1(3), $191-212$.

Pérez-Milans, M., \& Tollefson, J. (2018). Language policy and planning: Directions for future research. In J. W. Tollefson \& M. Pérez-Milans (Eds.), The Oxford handbook of language policy and planning (pp. 727-741). Oxford: Oxford University Press.

Piller, I., \& Lising, L. (2014). Language, employment and settlement: Temporary meat workers in Australia. Multilingua, 33(102), 35-59.

Pullin Stark, P. (2009). No joke-This is serious! Power, solidarity and humour in business English as a Lingua Franca (BELF) meetings. In A. Mauranen \& E. Ranta (Eds.), English as a Lingua Franca: Studies and findings (pp. 153-177). Newcastle: Cambridge Scholars Press.

Ricento, T. (Ed.). (2000). An introduction to language policy: Theory and method. Malden, MA: Blackwell Publishing.

Schluter, A. (2014). Competing or compatible language identities in Istanbul's Kurdish workplaces? In K. Kamp, A. Kaya, E. F. Keyman, \& O. O. Besgul (Eds.), Contemporary Turkey at a glance: Interdisciplinary perspectives on local and translocal dynamics. (pp. 125-138). New York: Springer.

Schneider, E. W. (2016). Grassroots Englishes in tourism interactions: How many speakers acquire 'grassroots English' in direct interactions, and what this may mean to them, and perhaps to linguists. English Today, 32(3), 2-10.

Schneider, B. (2018). Lobster, tourism and other kinds of business. Economic opportunity and language choice in a multilingual village in Belize. Language and Intercultural Communication, 18(4), $390-407$.

Schnurr, S., \& Zayts, O. (2017). Language and culture at work. London: Routledge.

Serwe, S. (in press). Investigating language use in immigrant businesses: Workplace practices of a Thai massage salon owner in Germany. In K. Gonçalves, \& H. Kelly-Holmes (Eds.), Language, global mobilities and blue-collar workplaces. New York: Routledge.

Shohamy, E. (2006). Language policy: Hidden agendas and new approaches. New York: Routledge.

Spolsky, B. (2009). Language management. Cambridge: Cambridge University Press.

Spolsky, B. (2018). Language policy: From planning to management. In C. C. S. Kheng, et al. (Eds.), Un(intended) language planning in a globalising world: multiple levels of players at work (pp. 301306). Warsaw: De Gruyter.

Standing, G. (2011). Workfare and the precariat. Soundings, 47, 35-43.

Stockdill, B. C., \& Danico, M. Y. (2012). Transforming the ivory tower. Honolulu: University of Hawaii Press.

Strömmer, M. (2016). Affordances and constraints: Second language learning in cleaning work. Multilingиа, 35(6), 697-721.

Sunaoshi, Y. (2005). Historical context and intercultural communication: Interactions between Japanese and American factory workers in the American South. Language in Society, 34(2), 185-218.

Thurlow, C. (Ed.). (2020). The business of words. Wordsmiths, linguists and other language workers. New York: Routledge.

Trip. G. (2019). There's no boom in youngstown, but blue-collar workers are sticking with trump. New York Times. https://www.nytimes.com/2019/05/20/us/politics/trump-voters-job-layoffs.html?searc hResultPosition=1.

Urciuoli, B., \& LaDousa, C. (2013). Language management/labor. Annual Review of Anthropology, 42, $175-190$.

Vertovec, S. (2009). Transnationalism. New York: Routledge. 
Vigouroux, C. B. (2017). Rethinking (un) skilled migrants: Whose skills, what skills, for what, and for whom? In S. Canagarajah (Ed.), The Routledge handbook of migration and language (pp. 312-329). New York: Routledge.

Vine, B. (Ed.). (2018). The Routledge handbook of language in the workplace. New York: Routledge.

Wickman, F. (2012). Working man's blues: Why do we call manual laborers blue collar? Slate, 1 May. Retrieved from: http://www.slate.com/articles/business/explainer/2012/05/blue_collar_white_colla r_why_do_we_use_these_terms.html.

Wolfram, W. (1993). Ethical considerations in language awareness programs. Issues in Applied Linguistics, 4(2), 225-255.

World Economic Forum. (2020). World Migration Report 2020. Retrieved from https://publications.iom. int/system/files/pdf/wmr_2020.pdf.

Wright, S. (2004). Language policy and planning: From nationalism to globalisation. New York: Palgrave Macmillan.

Publisher's Note Springer Nature remains neutral with regard to jurisdictional claims in published maps and institutional affiliations.

Kellie Gonçalves is currently a post-doctoral fellow at the University of Köln, Germany. She has previously held post-doc positions at MultiLing, University of Oslo, Norway (2017-2020) and the University of Bern, Switzerland (2010-2014). She obtained her PhD in Modern English Linguistics from the University of Bern, Switzerland and was a Marie Heim-Vögtlin Grant recipient (2015-2017) awarded by the Swiss National Science Foundation. Her research interests include multilingualism, semiotic landscapes, language and workplace studies, tourism discourse and women and leadership. In addition to her research interests in sociolinguistics, she is an advocate for gender equality and female leadership within academia. She is the author of Conversations of Intercultural Couples (De Gruyter, 2013), Labour Policies, Language Use and the 'New' Economy: The Case of Adventure Tourism (Palgrave Macmillan, 2020) and co-author of Domestic Workers Talk (with Anne Schluter) (Multilingual Matters, forthcoming). Her articles have appeared in International Journal of the Sociology of Language, Multilingua, International Journal of Multilingualism, and Gender and Language. 